\title{
Free-living marine polychaetes (Annelida) inhabiting hard-bottom substrates in Trinidad and Tobago, West Indies
}

\author{
Judith F. Gobin \\ Department of Life Sciences, University of the West Indies, St. Augustine, Trinidad and Tobago, West Indies; \\ Judith.Gobin@sta.uwi.edu \\ Received 26-III-2009. Corrected 25-VII-2009. Accepted 25-VIII-2009.

\begin{abstract}
As part of a larger comparative study, marine polychaete hard-bottom assemblages were surveyed using artificial substrate units (ASUs) deployed at four sites off the islands of Trinidad and Tobago. The polychaete fauna was represented by 19 families comprising 89 species. The syllid Exogone dispar was the most abundant polychaete followed closely by the serpulid Pseudovermilia occidentalis. At the family level, the polychaete fauna inhabiting the ASUs is similar to the fauna from other temperate and tropical locations. Omnivorous species were dominant (70\%), followed by filter feeders $(20 \%)$. This survey provides first records of the hard-bottom polychaete fauna of Trinidad and Tobago and adds new information about the geographic range of some polychaete species. Rev. Biol. Trop. 58 (1): 147-157. Epub 2010 March 01.
\end{abstract}

Key words: Polychaeta, diversity, abundance, rocky substrate, Caribbean, colonization.

The Caribbean is considered a unique biogeographic region with many endemic species and is among the top five world hotspots for marine and terrestrial biodiversity (RiveraMonroy et al. 2004). Of the various Caribbean benthic environments which support a high biodiversity of organisms- coral reefs have been the main focus of most of the macrobenthic studies.

There have been few studies of the macrofauna of the southern Caribbean (the West Indian chain of islands), and particularly the polychaete fauna. Two comprehensive lists of polychaete taxonomic literature for the Caribbean marine area have been produced by Perkins \& Savage (1975) and later by Salazar-Vallejo (1996). The earliest polychaete taxonomic reference to the Caribbean is Webster (1884) for Bermuda, while for the West Indies, it is Mullin (1923) for Antigua-Barbados. Marsden (1960) described the polychaetes from the shallow waters around Barbados while Turnbull (1979) described the macrofaunal communities in the Careenage Bay in Barbados. In Jamaica, Jones (1962) described several polychaetes and Wade (1976) described the polychaete distribution, composition and abundance (in soft sediments) in Kingston Harbour. Gillet (1986) described the polychaetes from two lagoons in Gaudeloupe. For Cuba, San Martin (eg.1986 and 1994) has produced a number of polychaete taxonomic papers. In nearby north-eastern Venezuela a number of polychaete taxonomic descriptions, have been published to date (Linero-Arana 1990, Linero-Arana \& Diaz 2006) while Bone \& Klein (2000) and Bone et al. (2007) have carried out a number of polychaete ecological studies. In Trinidad and Tobago, polychaetes in the coastal area off the Industrial Estate at Point Lisas (on the west coast) were described by Gobin (1988) while Gobin (1990) produced a checklist of polychaetes. The latter was based on a number of soft-bottom sediment benthic surveys which had been carried out primarily 
on the west coast of the island. Agard (1984) and Agard et al. (1993) described the soft-bottom macrobenthic intertidal communities of the north-western (Diego Martin to Port-of-Spain) and the south-west (San Fernando to La Brea) coastal areas including the polychaetes. Mackie \& Gobin (1993) also described a new maldanid species Johnstonia duplicata from Trinidad.

Polychaetes inhabiting hard-bottom substrates in the southern Caribbean island chain have been less well surveyed than their softbottom counterparts. While there have been some taxonomic studies on specific groups of attached polychaetes ( Tovar-Hernandez \& Salazar-Vallejo 2006, Tovar-Hernandez \& Salazar-Silva 2008) and from a few different habitat and substrate types (Giangrande et al. 2007); there have been very few polychaete diversity surveys of rock substrates. For example, in the Mexican (western) Caribbean, the serpulid polychaetes of hard bottom substrates were described by Bastida-Zavala \& SalazarVallejo (2000). Granados-Barba et al. (2003) examined the distribution and diversity of the polychaete family Syllidae from Veracruz, Campeche and Cozumel in both soft and hardbottom substrates.

Globally, various studies have utilized artificial substrates for examining macrofauna colonization on hard substrates (Ghelardi 1960, Schoener 1974, Hutchings 1981, Myers \& Southgate 1980, Costello 1988). Regionally Jackson (1977) studied colonization of tiles deployed on hard-substrates in Jamaica while much later in Barbados, Diaz-Castenada \& Almeda-Jauregui (1999) described the polychaetes colonising submerged coral plates.

This study is part of a larger global survey which was the subject of the author's doctoral research project (Gobin 1994, Gobin \& Warwick 2006). In that survey, artificial substrate units (ASUs) were used to examine diversity patterns of a single component of the macrobenthic (polychaetes) and meiobenthic (nematodes) communities inhabiting subtidal hard substrates at different latitudes. The geographic locations in that survey included the south-west coast of England in the United Kingdom (50
$\mathrm{N}$ ), the north western areas of Trinidad and Tobago $\left(10^{\circ} \mathrm{N}\right)$, New Zealand $\left(40-44^{\circ} \mathrm{S}\right.$ and Signy Island of the South Orkneys, in Antarctica $\left(63^{\circ} \mathrm{S}\right)$.

Only the polychaete component of the macrofaunal survey carried out at the Trinidad and Tobago sampling sites are discussed here. This paper provides the first records of freeliving polychaete fauna associated with hard substrates, for the southern Caribbean and Trinidad and Tobago, and adds to the knowledge of polychaete biodiversity for the islands.

\section{MATERIALS AND METHODS}

Subtidal rocky, hard bottoms (of depth approximately 12 to $15 \mathrm{~m}$ ) was the standard coastal substrate chosen for the global comparative study. Such subtidal substrates are not extensive around Trinidad and Tobago. Four stations (D, E, F and G) were chosen along the chain of tiny islands (known as "Five islands") off the north-west peninsula of Trinidad with the fifth $(\mathrm{H})$ off the north-west coast of Tobago (Fig. 1, after Gobin 2007). Station locations are as follows: D (Balata Bay, 1042'10.72" N, 61 ${ }^{\circ} 43^{\prime} 21.40^{\prime}$ W), E (Rust Bay, 10'41'1.47” N, 6144'15.54” W), F (Winds Bay, 10³9'48.62” N, $61^{\circ}$ '39'16.43” W), G (Macqueripe Bay, 1044'15.86" N, 61'37'19.50" W) and H (Mount Irvine Bay, $\left.11^{\circ} 11^{\prime} 17.85^{\prime \prime} \mathrm{N}, 60^{\circ} 47^{\prime} 50.59^{\prime \prime} \mathrm{W}\right)$.

Five ASUs were deployed at each of the 5 stations (total of 25 ASUs) in Trinidad and Tobago, between January and February 1991. Each artificial substrate unit (ASU) consisted of four nylon pads (pan-scourers) held on a stainless steel piton (Fig. 2, after Gobin 2007). All deployment and retrieval of ASUs were done by SCUBA divers of the Institute of Marine Affairs (IMA) in Trinidad. Each ASU was imbedded into a rocky substrate (rock ledge or crevice) and were collected approximately five months, after deployment. This period having been earlier established as optimal for colonization onto the substrates (Gobin 1994).

As described in Gobin \& Warwick (2006), all fauna attached to and trapped in the mesh 


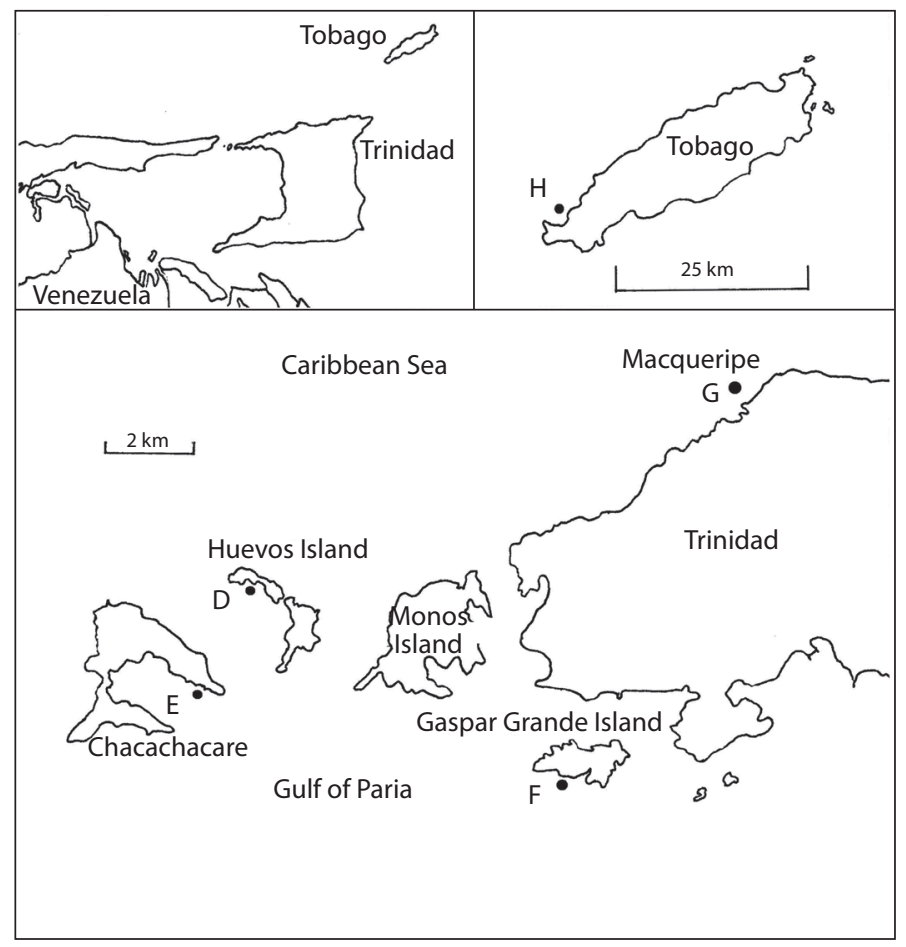

Fig. 1. Location of sampling stations D, E, F, G and H off Trinidad and Tobago (after Gobin 2007).

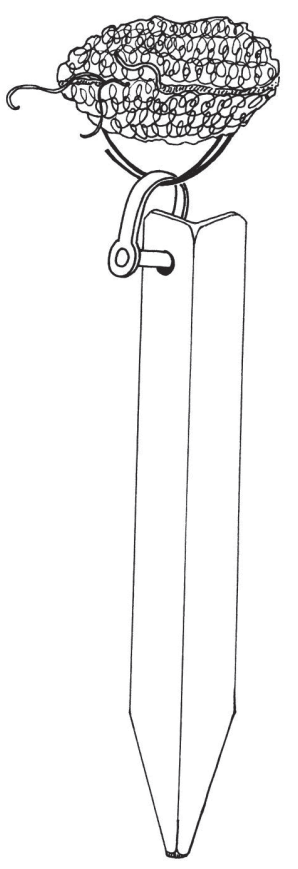

was also collected and the entire content of each container was then carefully washed over two sieves: one with mesh size of $125 \mu \mathrm{m}$ size (to retain the macrofauna) and one with mesh size of $63 \mu \mathrm{m}$ (to retain the meiofauna). The macrofauna sample was again washed to remove all formalin and the organisms were sorted into 2 groups- polychaetes and all others. From each station, 4 replicate samples were used in the analyses. All polychaetes were counted and identified as far as possible to species level. Comprehensive polychaete taxonomic keys (Uebelacker \& Johnson 1984) were used for identifications and putative species were assigned to those organisms which were recognized at the family level. Verification of

Fig. 2. Components of the artificial substrates unit (ASU) used for sampling polychaetes (after Gobin 2007). 
identifications were carried out by Dr. Mike Kendall (Plymouth Marine Laboratory). The polychaete collection is housed with the author and is presently being catalogued for deposition in the National Biodiversity Centre (at the University of the West Indies, St. Augustine Campus, Trinidad and Tobago).

To describe the polychaete communities abundances, numbers of species and species diversity- the Shannon-Wiener index H'(Shannon \& Weaver 1965 were calculated for each station. $k$-dominance curves (Lambshead et al. 1983) in which cumulative species abundances are plotted against species rank were also plotted for all stations. A one-way parametric analyses of variance (ANOVA) test (Kruskal \& Wallis 1978) was performed on the pooled set of samples to determine if there were significant differences in diversity between stations.

\section{RESULTS}

In general, there was a very diverse community of organisms colonizing the ASUs. This discrete assemblage consisted mainly of polychaetes, amphipods, copepods, isopods, asteroids, decapods, gastropods, ascideans and bivalves (Gobin, 1994). Of the macrofaunal component (total of 4 replicates), 2377 polychaetes were counted and identified. They belonged to 19 families and comprised 89 species. A complete family/species list (combined stations) is presented in Table 1.
Taxonomic analysis suggest that more than $25 \%$ of the polychaetes could be new species, including one new genus of Hesionidae (M. Kendall pers comm.). The family Syllidae was highly successful as colonists having the highest representation by both species (30) and individuals (1 646). In fact, the Syllidae comprised approximately $70 \%$ of the total abundance with the families Serpulidae and Sabellidae as the next most abundant (combined $18 \%$ ) in terms of total numbers of individuals. The top 3 abundant species were the syllid Exogone dispar (231 individuals), followed by the serpulid Pseudovermilia occidentalis (228) and the syllid Haplosyllis spongicola (Grube 1855) (166).

$k$-dominance curves (Fig. 3) which were plotted for the summed replicates (four at each station) reflect similarities in polychaete diversity at all stations. An Analysis of Variance (ANOVA) was performed to test the differences between these diversities (as well as abundances and total numbers of species) for the 5 stations. However, there were no significant differences between stations $(p=0.508)$ in terms of diversities, abundances and numbers of species.

The polychaete family data were used to group families into trophic guilds following Fauchald \& Jumars (1979). Overall dominance was by omnivores $(70 \%)$, reflecting dominance by the Syllidae. Filter feeders accounted for approximately $18 \%$ of the total and was due to

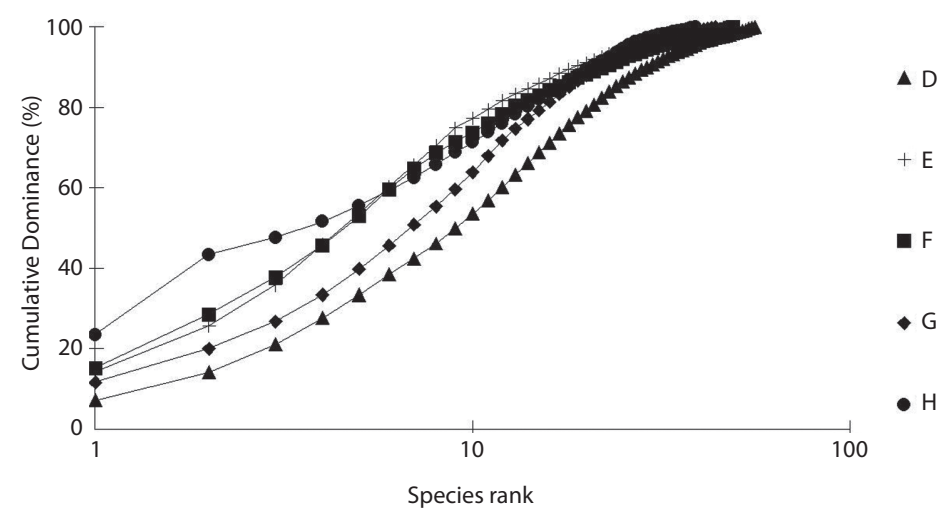

Fig. 3. Polychaete $k$-dominance curves for stations D, E, F, G and H. 
TABLE 1

Polychaete (Phylum Annelida) families and species list for stations D, E, F, G and H, including total numbers of individuals collected. Family totals are italicized and *-denotes new records for Trinidad and Tobago

\begin{tabular}{|c|c|c|c|c|c|c|c|}
\hline \multirow{2}{*}{ Family } & \multirow{2}{*}{ Species } & \multicolumn{6}{|c|}{ Number of Individuals } \\
\hline & & $\mathrm{D}$ & $\mathrm{E}$ & $\mathrm{F}$ & $\mathrm{G}$ & $\mathrm{H}$ & Total \\
\hline \multirow[t]{2}{*}{ Ampharetidae } & Ampharetid sp. 1 & 4 & 0 & 2 & 5 & 9 & 20 \\
\hline & & & & & & & 20 \\
\hline \multirow[t]{2}{*}{ Aphroditidae } & *Pontogenia sp. 1 (Claparede, 1868) & 1 & 0 & 1 & 1 & 16 & 19 \\
\hline & & & & & & & 19 \\
\hline \multirow[t]{2}{*}{ Chaetopteridae } & Chaetopterus sp. 1 (Cuvier, 1827) & 2 & 0 & 0 & 0 & 0 & 2 \\
\hline & & & & & & & 2 \\
\hline \multirow[t]{2}{*}{ Dorvilleidae } & Dorvillea sp. 1 (Parfitt, 1866) & 1 & 0 & 0 & 0 & 0 & 1 \\
\hline & & & & & & & 1 \\
\hline \multirow[t]{5}{*}{ Eunicidae } & *Eunice antennata (Savigny, 1820) & 3 & 2 & 1 & 1 & 0 & 7 \\
\hline & *Eunice vittata (Delle Chiaje, 1828) & 0 & 0 & 1 & 0 & 0 & 1 \\
\hline & *Eunice websteri (Fauchald, 1969) & 0 & 2 & 0 & 0 & 1 & 3 \\
\hline & *Marphysa mortensi (Monro, 1928) & 0 & 0 & 1 & 1 & 1 & 3 \\
\hline & & & & & & & 14 \\
\hline \multirow[t]{2}{*}{ Flabelligeridae } & *Pherusa sp. 1 (Oken, 1807) & 0 & 0 & 0 & 1 & 0 & 1 \\
\hline & & & & & & & 1 \\
\hline \multirow[t]{4}{*}{ Hesionidae } & Hesione picta (Muller, 1858) & 1 & 1 & 0 & 0 & 0 & 2 \\
\hline & Hesionid genus a & 0 & 0 & 0 & 0 & 4 & 4 \\
\hline & Podarke sp. 1 (Ehlers, 1864) & 0 & 0 & 1 & 2 & 1 & 4 \\
\hline & & & & & & & 10 \\
\hline \multirow[t]{2}{*}{ Lumbrineridae } & Lumbrinerid sp. 1 & 0 & 0 & 2 & 0 & 0 & 2 \\
\hline & & & & & & & 2 \\
\hline \multirow[t]{2}{*}{ Maldanidae } & *Axiothella sp.1 (Verrill, 1900) & 3 & 0 & 0 & 0 & 0 & 3 \\
\hline & & & & & & & 3 \\
\hline \multirow[t]{4}{*}{ Nereididae } & Nereid sp. 1 & 7 & 65 & 2 & 1 & 1 & 76 \\
\hline & *Nereis pelagica (Linnaeus, 1758) & 4 & 2 & 0 & 6 & 0 & 12 \\
\hline & $\begin{array}{l}\text { *Platynereis dumerilli (Audouin \& Milne Edwards, } \\
\text { 1833) }\end{array}$ & 1 & 0 & 2 & 1 & 0 & 4 \\
\hline & & & & & & & 92 \\
\hline \multirow[t]{2}{*}{ Oenonidae } & *Arabella iricolor (Montagu, 1804) & 0 & 0 & 0 & 0 & 1 & 1 \\
\hline & & & & & & & 1 \\
\hline \multirow[t]{2}{*}{ Ophelidae } & *Armandia sp. 1 (Filippi, 1861) & 7 & 0 & 1 & 0 & 0 & 8 \\
\hline & & & & & & & 8 \\
\hline \multirow[t]{5}{*}{ Phyllodocidae } & Eteone heteropoda (Hartman, 1951) & 0 & 3 & 0 & 2 & 0 & 5 \\
\hline & Eteone lactea (Claparède, 1868) & 1 & 1 & 1 & 1 & 1 & 5 \\
\hline & *Mystides borealis (Théel, 1879) & 0 & 0 & 0 & 0 & 3 & 3 \\
\hline & Phyllodoce sp. 1 (Lamarck, 1818) & 0 & 0 & 0 & 5 & 0 & 5 \\
\hline & & & & & & & 18 \\
\hline \multirow[t]{5}{*}{ Polynoidae } & Harmothoe sp. 1 (Kinberg, 1855) & 10 & 5 & 9 & 1 & 12 & 37 \\
\hline & *Lepidonotus sublevis (Verrill, 1873) & 2 & 0 & 0 & 2 & 2 & 6 \\
\hline & *Lepidonotus variabilis (Webster, 1879) & 0 & 1 & 0 & 0 & 0 & 1 \\
\hline & Polynoid sp. 1 & 3 & 0 & 3 & 0 & 0 & 6 \\
\hline & & & & & & & 50 \\
\hline \multirow[t]{2}{*}{ Sabellidae } & Chone americana (Day, 1973) & 31 & 11 & 28 & 30 & 17 & 117 \\
\hline & Fabricia sp. 1 (Blainville, 1828) & 1 & 0 & 0 & 0 & 0 & 1 \\
\hline
\end{tabular}


TABLE 1 (Continued)

Polychaete (Phylum Annelida) families and species list for stations D, E, F, G and H, including total numbers of individuals collected. Family totals are italicized and *-denotes new records for Trinidad and Tobago

\begin{tabular}{|c|c|c|c|c|c|c|c|}
\hline \multirow{2}{*}{ Family } & \multirow{2}{*}{ Species } & \multicolumn{6}{|c|}{ Number of Individuals } \\
\hline & & $\mathrm{D}$ & $\mathrm{E}$ & $\mathrm{F}$ & G & $\mathrm{H}$ & Total \\
\hline \multirow{10}{*}{ Serpulidae } & *Sabella melanostigma (Schmarda, 1861) & 5 & 3 & 1 & 0 & 10 & 19 \\
\hline & *Sabella sp. 1 (Linnaeus, 1767) & 1 & 3 & 8 & 5 & 1 & 18 \\
\hline & *Sabella sp. 2 (Linnaeus, 1767) & 14 & 4 & 5 & 0 & 1 & 24 \\
\hline & *Sabella sp. 3 (Linnaeus, 1767) & 12 & 5 & 1 & 0 & 0 & 18 \\
\hline & & & & & & & 197 \\
\hline & *Hydroides bispinosa (Bush, 1910) & 0 & 1 & 1 & 0 & 0 & 2 \\
\hline & *Hydroides sp. 1 (Gunnerus, 1768) & 0 & 0 & 0 & 1 & 0 & 1 \\
\hline & *Pseudovermilia occidentalis (McIntosh, 1885) & 17 & 31 & 52 & 34 & 94 & 228 \\
\hline & *Serpula sp. 1 (Linnaeus, 1758) & 0 & 0 & 0 & 2 & 0 & 2 \\
\hline & & & & & & & 233 \\
\hline \multirow[t]{7}{*}{ Spionidae } & *Boccardiella sp. 1 (Blake \& Kudenov, 1978) & 0 & 1 & 0 & 0 & 0 & 1 \\
\hline & Polydora sp. 1 (Bosc, 1802) & 1 & 0 & 1 & 0 & 0 & 2 \\
\hline & Polydora sp. 2 (Bosc, 1802) & 0 & 0 & 0 & 2 & 0 & 2 \\
\hline & *Prionospio cirrobranchiata (Day, 1961) & 4 & 0 & 1 & 0 & 0 & 5 \\
\hline & Prionospio sp. 1 (Malmgren, 1867) & 16 & 0 & 3 & 0 & 0 & 19 \\
\hline & Spiophanes sp. 1 (Grube, 1860) & 0 & 5 & 0 & 0 & 0 & 5 \\
\hline & & & & & & & 34 \\
\hline \multirow[t]{27}{*}{ Syllidae } & *Amblyosyllis sp.1 (Grube, 1857) & 14 & 8 & 3 & 33 & 2 & 60 \\
\hline & *Branchiosyllis sp. 1 (Ehlers, 1887) & 1 & 8 & 1 & 0 & 0 & 10 \\
\hline & *Brania clavata (Claparede, 1863) & 2 & 28 & 3 & 1 & 0 & 34 \\
\hline & *Eusyllis kuppferi (Langerhans, 1879) & 0 & 0 & 0 & 22 & 0 & 22 \\
\hline & *Eusyllis lamelligera (Marion \& Bobretzky, 1875) & 7 & 8 & 15 & 23 & 13 & 66 \\
\hline & *Eusyllis sp. 1 (Ehlers, 1864) & 30 & 74 & 26 & 27 & 9 & 166 \\
\hline & *Exogone dispar (Webster, 1879) & 3 & 0 & 0 & 11 & 1 & 15 \\
\hline & Exogone lourei (Berkeley \& Berkeley, 1938) & 12 & 65 & 1 & 60 & 8 & 146 \\
\hline & Exogone sp. 1 (Orsted, 1845) & 9 & 0 & 59 & 0 & 0 & 68 \\
\hline & *Haplosyllis spongicola (Grube, 1855) & 8 & 16 & 1 & 35 & 5 & 65 \\
\hline & *Myrianida dentalia (Imajima, 1966) & 2 & 8 & 1 & 12 & 10 & 33 \\
\hline & *Myrianida sp. 1 (Milne Edwards, 1845) & 14 & 14 & 20 & 0 & 4 & 52 \\
\hline & *Myrianida sp. 2 (Milne Edwards, 1845) & 30 & 43 & 36 & 15 & 7 & 131 \\
\hline & *Myrianida sp. 3 (Milne Edwards, 1845) & 10 & 34 & 9 & 5 & 5 & 63 \\
\hline & *Odontosyllis sp. 1 (Claparede, 1863) & 22 & 5 & 3 & 10 & 5 & 45 \\
\hline & *Opisthodonta sp. 1 (Langerhans, 1879) & 3 & 2 & 4 & 9 & 4 & 22 \\
\hline & Pionosyllis sp. 1 (Malmgren, 1867) & 28 & 49 & 31 & 43 & 80 & 231 \\
\hline & *Pionosyllis wiesmanni (Langerhans, 1879) & 1 & 2 & 1 & 8 & 6 & 18 \\
\hline & *Sphaeosyllis longicauda (Webster \& Benedict, 1887) & 6 & 3 & 1 & 3 & 0 & 13 \\
\hline & *Sphaerosyllis sp. 1 (Claparede, 1863) & 2 & 5 & 3 & 2 & 2 & 14 \\
\hline & *Streptospinigera sp. 1 (Kudenov, 1983) & 1 & 0 & 0 & 0 & 0 & 1 \\
\hline & Syllid sp. 1 & 1 & 2 & 0 & 7 & 0 & 10 \\
\hline & *Syllides sp. 2 (Orsted, 1845) & 16 & 91 & 11 & 21 & 13 & 152 \\
\hline & *Syllis gracilis (Grube, 1857) & 2 & 0 & 0 & 0 & 0 & 2 \\
\hline & *Syllis prolifera (Krohn,1852) & 7 & 14 & 5 & 22 & 15 & 63 \\
\hline & Syllis sp. 1 (Savigny, 1820) & 25 & 1 & 9 & 20 & 16 & 71 \\
\hline & Syllis sp. 2 (Savigny, 1820) & 0 & 1 & 0 & 0 & 0 & 1 \\
\hline
\end{tabular}


TABLE 1 (Continued)

Polychaete (Phylum Annelida) families and species list for stations D, E, F, G and H, including total numbers of individuals collected. Family totals are italicized and *- denotes new records for Trinidad and Tobago

\begin{tabular}{|c|c|c|c|c|c|c|c|}
\hline \multirow{2}{*}{ Family } & \multirow{2}{*}{ Species } & \multicolumn{6}{|c|}{ Number of Individuals } \\
\hline & & $\mathrm{D}$ & $\mathrm{E}$ & $\mathrm{F}$ & G & $\mathrm{H}$ & Total \\
\hline \multirow{10}{*}{ Terebellidae } & Syllis sp. 3 (Savigny, 1820) & 2 & 2 & 2 & 0 & 0 & 6 \\
\hline & Syllis sp. 4 (Savigny, 1820) & 16 & 4 & 5 & 7 & 4 & 36 \\
\hline & *Trypanosyllis sp. 1 (Claparede, 1864) & 1 & 7 & 4 & 11 & 7 & 30 \\
\hline & & & & & & & 1646 \\
\hline & Loimia sp. 1 (Malmgren, 1866) & 1 & 1 & 0 & 0 & 0 & 2 \\
\hline & *Polycirrus sp. 1 (Grube, 1850) & 2 & 0 & 4 & 0 & 0 & 6 \\
\hline & Terebellid sp. 1 & 0 & 0 & 3 & 4 & 6 & 13 \\
\hline & Terebellid sp. 2 & 1 & 0 & 0 & 0 & 4 & 5 \\
\hline & & & & & & & 26 \\
\hline & Total polychaetes & 431 & 641 & 389 & 515 & 401 & 2377 \\
\hline
\end{tabular}

abundances of both Serpulidae and Sabellidae. The remaining families comprised carnivores $(8 \%)$ and deposit feeders (4\%). The range and proportional representation of feeding modes supported by the ASUs is indicative of the diverse nature of the available food sources in the artificial habitat.

This study adds 3 new families (Flabelligeridae, Oenonidae and Aphroditidae) and 47 new records of polychaete species (Table 1) to the earlier species list recorded by Gobin (1990). Current biodiversity figures are a total of 201 polychaete species from 41 families for Trinidad and Tobago.

\section{DISCUSSION}

The hard substrate sub-tidal polychaete fauna of Trinidad and Tobago was found to consist of similar families and genera as in other geographic areas such as New Zealand and the south west coast of England (Gobin 1994, Gobin \& Warwick 2006). The Trinidad and Tobago rocky-substrate polychaete fauna also shows general similarity (in terms of dominance and composition) to previously described Caribbean faunal assemblages. For example in Barbados, Diaz-Castaneda \& Almeda-Jauregui (1999) found polychaetes to be the most abundant and diverse zoological group on submerged coral plates with the families Syllidae and Serpulidae being the most abundant (as in this survey) at their 2 survey sites. Granados-Barba et al. (2003) also reported successful dominance by Syllidae in the hard bottom (coralline substrates).

The numerical dominance of the syllids in the ASUs was expected as syllids are most frequent in shallow water associated with hard substrata and are especially abundant on coral reefs (Kohn \& Lloyd 1973). They are often the most abundant and diverse of polychaete families in sponges and hard corals, creeping actively through their channels or crevices (Uebelacker \& Johnson 1984). The ASU provided a network of holes or crevices and also created an accumulation of sediment affording a degree of shelter and protection for the worms. The omnivorous Syllinae accounted for more than $50 \%$ of the total Syllidae while the Exogoninae which are selective deposit feeders of mud or detritus (Uebelacker \& Johnson 1984) and to which diatoms are an important food source for some species (Fauchald \& Jumars 1979), were also well represented (approx. $27 \%$ of the total Syllidae). The rich epigrowth resource of bacteria and diatoms available on and within the ASUs explains their abundance. Many of the syllid genera are also 
carnivorous (eg. species of Myrianida) and utilize their pharyngeal armature to ingest prey.

The Serpulidae are typically hard substrate dwellers since they are tube-dwelling (calcareous) polychaetes and are common fouling communities on hard surfaces (Uebelacker \& Johnson 1984). These filterfeeders use their tentacular crown to filter phytoplankton from the water column. The abundance of Pseudovermilia occidentalis in the ASUs is therefore also expected. The larvae of some polychaete species are known to settle preferentially in the presence of adults (Marsden \& Anderson 1981) and this behaviour may additionally explain the abundance of Pseudovermilia occidentalis. Together with the Sabellidae, they comprised the main components of the filterfeeding group.

The overall similarity in species diversity at all stations is explained by virtue of their location. The offshore islands' stations (D, E, F and G) are directly influenced by the outflow from the Gulf of Paria which is itself influenced by outflows from the larger South American rivers. However, these stations are also proximal and therefore influenced also by the more oceanic Caribbean Sea with station $\mathrm{H}$ being moreso. Local hydrographic conditions (not measured) may have influenced the concentrations of marine organisms. Overall, it is expected that animals colonized mostly as settling larvae and/or juveniles transported by water currents as well as active adults may have crawled or swam onto the ASUs (see also Diaz-Castenada \& Almeda-Jauregui 1999).

Artificial substrates are used routinely to assess water quality in estuaries in many countries (De Pauw et al. 1981). They are ideal to alleviate some of the problems associated with standardized sample collections and especially so, where orthodox sampling methods cannot be used eg. hard bottom surfaces. There is though, some debate about whether artificial substrates are truly representative of natural substrates in terms of colonization by natural communities (Atilla et al. 2003, Danovaro \& Fraschetti 2002, Smith \& Rule 2002). For example, Smith \& Rule (2002) found that assemblages in scourers with direct contact to the substratum were more similar to natural assemblages than those in scourers suspended in the water-column while Danovaro \& Fraschetti (2002) found that they were radically different.

While comparisons with nearby sediment fauna are not possible as concurrent collections were not part of the original survey (Gobin 1994), the success of ASUs in this research is clear in terms of sampling the hard-substrate polychaetes of Trinidad and Tobago. Macrofaunal studies using similar artificial substrates (nylon pan scourers) have previously provided valuable information on benthic communities (Schoener 1974, Myers \& Southgate 1980, Costello 1988). Since changes in spatial and temporal distributions of polychaetes (and other macrofauna) may be due to natural occurrences, physical perturbation, pollution effects or a combination of these- such information is invaluable. As part of the Environmental Management approach (National Environmental Policy of Trinidad and Tobago, 1998) in Trinidad and Tobago, benthic macrofaunal surveys are often a compulsory requirement within the Terms of Reference (TORs) of Environmental Impact Assessments (EIAs). This since marine macrofaunal organisms (generally dominated by polychaetes) are important constituents of trophic webs, being a valuable food source for larger organisms such as fish. A knowledge of the polychaete macrofauna is therefore important in evaluating assessment of impacts given Trinidad and Tobago's very active offshore oil and gas production. Such data are crucial to the sustainability of the rich fishery associated with Trinidad and Tobago's coastal waters.

The paucity of relevant taxonomic information and polychaete distribution data for the Caribbean territories has been highlighted recently in the various country-specific reviews of Caribbean and sub-tropical marine biodiversity (Miloslavich \& Klein 2005).

Totals of polychaete species listed for countries reviewed include: Costa Rica (4 species-Cortes \& Wehrtmann 2005), Cuba 
(>380 species- Ortiz \& Lalana 2005), Dominican Republic (unknown- Geraldes \& Vega 2005), Puerto Rico (129 species- Weil 2005), Venezuela (344 species- Milosavich et al. 2005) and Jamaica (estimate of 100 speciesWarner \& Goodbody 2005). The obvious gaps in information re-emphasize the need for improving our knowledge of biodiversity of such marine groups.

To date there is still very little known about the motile marine invertebrate fauna of shallow sublittoral habitats in the waters of Trinidad and Tobago. This research has provided the first species list of one of these groups- hard substrate marine polychaetes for Trinidad and Tobago and the Southern Caribbean. At the same time, it confirms the presence of various undescribed species for the area. Further taxonomic studies are critical in order to continue building on our local and regional biodiversity data. This paper is a contribution to the coastal and marine biodiversity data for Trinidad and Tobago.

\section{ACKNOWLEDGMENTS}

The deployment and retrieval of the ASUs were carried out by a few staff members of the Institute of Marine Affairs (IMA), Trinidad - C. Rooks, V. Jardine, L. Lee- Lum, R. Hubbard with assistance from R. Quintero and C. Cohen. The IMA is therefore acknowledged for all it's assistance including the granting of study leave to the author. Taxonomic assistance and verifications of polychaetes was provided by M. Kendall of Plymouth Marine Laboratory, United Kingdom. Sincere thanks to A. Singh for all her assistance including the preparation of figures.

\section{RESUMEN}

Como parte de un estudio comparativo más amplio, ensamblajes marinos de poliquetos de fondos duros fueron contabilizados utilizando unidades de sustrato artificial ubicadas en cuatro sitios de las islas de Trinidad y Tobago. La fauna de poliquetos estuvo representada por 19 familias, integradas por 89 especies. Exogone dispar fue el poliqueto más abundante seguido cercanamente por Pseudovermilia occidentalis. A nivel de familia, la fauna de poliquetos que habitan las unidades de sustrato artificial es similar a la de otras localidades templadas y tropicales. Las omnívoras fueron las especies dominantes $(70 \%)$, seguido por las filtradoras $(20 \%)$. Este estudio proporciona los primeros registros de la fauna de poliquetos del fondo duro de Trinidad y Tobago, y añade nueva información sobre la distribución geográfica de algunas especies de poliquetos.

Palabras clave: Polychaeta, diversidad, abundancia, substrato rocoso, Caribe, colonización.

\section{REFERENCES}

Agard, J.B. 1984. A Baseline survey of the effects of Pollution on the benthos of the nearsgore Diego-Martin to port-of-Spain coastal area. I.M.A. Technical Report, Institute of Marine Affairs, Chaguaramas, Trinidad, West Indies.

Agard, J.B.R., R.M. Warwick \& J. Gobin. 1993. Analysis of marine macrobenthic community structure in relation to pollution, natural oil seepage and seasonal disturbance in a tropical environment (Trinidad, West Indies). Mar. Ecol. Prog. Ser. 92: 233-243.

Atilla, N., M.A. Wetzel \& J.W. Fleeger. 2003. Abundance and colonization potential of artificial hard substrateassociated meiofauna. J. Exp. Mar. Biol. Ecol. 287: 273-287.

Bastida-Zavala, J.R. \& S.I. Salazar-Vallejo. 2000. Serpúlidos (Polychaeta: Serpulidae) del Caribe noroccidental con claves para la región del Gran Caribe: Salmacina, Ficopomatus, Pomatoceros, Pomatostegus, Protula, Pseudovermilia, Spirobranchus y Vermiliopsis. Rev. Biol. Trop. 48: 807-840.

Bone, D. \& E. Klein. 2000. Temporal variations in a tropical soft-bottom community, Venezuela. J. Coast. Res. 16: 278-286.

Bone, D., I. Chollett \& C.T. Rodriguez. 2007. Macrobentos de aguas profundas en la costa atlántica Venezolana. Interciencia 32: 477-481.

Cortes, J. \& I.S. Wehrtmann. 2005. Costa Rica, p. 169-179. In P. Miloslavich \& E. Klein (eds.). Caribbean Marine Biodiversity: The known and the unknown. DEStech Publications Inc., Pennsylvania, USA.

Costello, M. J. 1988. Studies on amphipod crustaceans in Lough Hyne, Ireland. Ph.D. Thesis, Trinity University, Dublin, Ireland. 
Danovaro, R. \& S. Fraschetti. 2002. Meiofaunal vertical zonation on hard-bottoms: comparison with softbottom meiofauna. Mar. Ecol. Prog. Ser. 311: 47-61.

De Pauw, N., D. Roels \& A. P. Fontoura. 1981. Use of artificial substrates for standardized sampling of macroinvertebrates in the assessment of water quality by the Belgian Biotic Index. Hydrobiologia 133: 237-258.

Diaz- Castenada, V. \& C. Almeda- Jauregui. 1999. Early Benthic Organism Colonization on a Caribbean Coral Reef (Barbados,West Indies): a Plate Experimental Approach. P.S. Z.N. Mar. Ecol. 20: 197-220.

Fauchald, K. \& P.A. Jumars. 1979. The Diet of Worms- a study of polychaete feeding guilds. Oceanogr. Mar. Biol. Annu. Rev. 17: 193-284.

Geraldes, F.X. \& M.B. Vega. 2005. Dominican Republic, p. 71-83. In P. Miloslavich \& E. Klein (eds). Caribbean Marine Biodiversity: The known and the unknown. DEStech Publications Inc., Pennsylvania, USA.

Ghelardi, R. J. 1960. Structure and dynamics of the animal community found in Macroystis pyrifera holdfasts. Ph.D. Thesis, University of California, La Jolla, USA.

Giangrande, A. M. L. \& M.C. Gambi. 2007. A collection of Sabellidae (Polychaeta) from Carrie Bow (Belize, western Caribbean sea) with the description of two new species. Zootaxa 1650: 41-53.

Gillet, P. 1986. Contribution to the study of Polychaete annelids from the lagoons at Manche-a-eau and Belle plaine (Guadeloupe). Description of a new Capitellidae: Scyphoproctus guadalupensis n.sp. Bulletin du Muséum national d'histoire naturelle. Section A, Zoologie, biologie et écologie animals. 8: 803-817.

Gobin, J. 1988. The polychaete macrofauna near a large Industrial Complex at Point Lisas, Gulf of Paria, Trinidad. M.Phil. Thesis, University of the West Indies, St. Augustine, Trinidad and Tobago.

Gobin, J. 1990. A checklist of marine polychaetous annelids (Polychaeta) for the Gulf of Paria, Trinidad, West Indies. Caribb. Mar. Stud. 1: 37-47.

Gobin, J. F. 1994. Latitudinal gradients in species diversity: A comparative study of marine macrobenthic and meiobenthic communities. Ph.D. Thesis, University of Exeter, Exeter, UK.

Gobin, J.F. \& R.M. Warwick. 2006. Geographical variation in species diversity: A comparison of marine polychaetes and nematodes. J. Exp. Mar. Biol. Ecol. 330: 234-244.
Gobin, J.F. 2007. Free-living marine nematodes of hard bottom substrates in Trinidad and Tobago, West Indies. Bull. Mar. Sci. 81: 73-84.

Granados-Barba, A., V. Solis-Weiss, M. Tovar-Hernandez \& V. Ochoa-Rivera. 2003. Distribution and diversity of the Syllidae (Annelida: Polychaeta) from the Mexican Gulf of Mexico and Caribbean. Hydrobiologia 496: 337-345.

Hutchings, P.A. 1981. Polychaete recruitment on to dead coral substrates at Lizard Island, Great Barrier Reef, Australia. Bull. Mar. Sci. 31: 410-423.

Jackson, J.B.C. 1977. Habitat area, colonization and development of epibenthic community structure. In B. F. Keegan, P.O. Ceidigh and P. J. S Boaden (eds.). Biology of benthic organisms. Pergamon Press, Oxford and New York, USA.

Jones, M. L. 1962. On some polychaetous annelids from Jamaica, the West Indies. Bull. Am. Mus. Nat. Hist. 124: $169-212$.

Kohn, A. J. \& M.C. Lloyd. 1973. Polychaetes of truncated reef limestone substrates on Eastern Indian Ocean coral reefs: diversity, abundance, and taxonomy. Int. Rev. Hydrobiol. 58: 369-399.

Kruskal, J.B. \& M. Wallis. 1978. Multidimensional scaling. Sage Publications, Beverley Hills, California, USA.

Lambshead, P.J.D., H.M. Platt \& K.M. Shaw. 1983. The detection of differences among assemblages of marine benthic species based on an assessment of dominance and diversity. J. Nat. Hist. 17: 859-874.

Linero-Arana, I. 1990. Poliquetos errantes bentonicos de la plataforma continental nor-oriental de Venezuela, 2. Eunicidae. Bol. Inst. Oceanogr. Univ. Oriente 24: 91-103.

Linero-Arana, I \& O. Diaz. 2006. Polychaeta (Annelida) associated with Thalassia testudinum in the northeastern coastal waters of Venezuela. Rev. Biol. Trop. 54: 971-978.

Mackie, A.S.Y. \& J.F. Gobin. 1993. A review of the genus Johnstonia, Quatrefages, 1886 (Polychaeta, Annelida), with a description of a new species from Trinidad, West Indies. Zoolog. Scripta 22: 229-241.

Marsden, J.R. 1960. Polychaetous annelids fro the shallow waters of Barbados and other West Indian islands. Can. J. Zool. 38: 989-1020. 
Marsden, J.R. \& D.T. Anderson. 1981. Larval development and meta- morphosis of the serpulid polychaete Galeolaria caespitosa. Mar. Biol. 83: 13-16.

Miloslavich, P. \& E. Klein, 2005. Linking marine biodiversity research and conservation in the Caribbean, p. 3-18. In P. Miloslavich \& E. Klein (eds.). Caribbean Marine Biodiversity: The known and the unknown. DEStech Publications Inc., Pennsylvania, USA.

Miloslavich, P., E. Klein, A. Martin, C. Bastidas, B. Marin \& P. Spiniello. 2005. Venezuela, p. 109-136. In P. Miloslavich \& E. Klein (eds.). Caribbean Marine Biodiversity: The known and the unknown. DEStech Publications Inc., Pennsylvania, USA.

Mullin, C.A. 1923. Reports on some polychaetous annelids collected by the Barbados-Antigua Expediton for the University of Iowa in 1918. Univ. Iowa. Stud. Nat. Hist. 10: 39-60.

Myers, A.A. \& T. Southgate. 1980. Artificial substrates as a means of monitoring rocky shore cryptofauna. J. Mar. Biol. Assoc. UK. 60: 963-975.

National Environmental Policy (NEP) of Trinidad and Tobago. 1998. A document prepared by the Ministry of Environment, Trinidad and Tobago.

Ortiz, M. \& R. Lalana. 2005. Cuba, p. 37-55. In Caribbean Marine Biodiversity: The known and the unknown. DEStech Publications Inc., Pennsylvania, USA.

Perkins, T.H \& T. Savage. 1975. A Bibliography and checklist of Polychaetous Annelids of Florida, the Gulf of Mexico and the Caribbean Region. Fla. Mar. Res. Publ. 14: 1-62.

Rivera-Monroy, V.H., R.R. Twilley, D. Bone, D.L. Childers, R.C. Coronado-Molina, I.C. Feller, J. HerrerraSilveira, R. Jaffe, E. Mancera, E. Rejmankova, J.E. Salisbury \& E. Weil. 2004. A conceptual framework to develop long-termecological research and management objectives in the wider Caribbean region. BioScience 54: 843-856.

Salazar-Vallejo, S.I. 1996. Lista de species y bibliografia de poliquetos (Polychaeta) del Gran Caribe. Anales Inst. Biol. Univ. Nac. Auton. Mexico, Ser. Zool. 67: 11-50.

San Martin, G. 1986. Acanthopale oerkinsi gen. et sp. n (Polychaeta, Chrysopetalidae) from Cuba and Florida. Zool. Scripta. 15: 305-312.
San Martín G., E. López \& M. Jimenéz. 1994. Sabellidae (Polychaeta) de la I Expedición Cubano-Española a la Isla de la Juventud y Archipiélago de los Canarreos (Cuba). Rev. Biol. Trop. 42: 555-565.

Schoener, A. 1974. Experimental zoogeography: colonization of marine mini-islands. Am. Nat. 108: 715-738.

Shannon, C.E. \& W. Weaver. 1965. The mathematical theory of communities. University of Illinois Press, Urbana, Illinois, USA.

Smith, S.D.A. \& M.J. Rule. 2002. Artificial substrata in a shallow sublittoral habitat: do they adequately represent natural habitats or the local species pool? J. Exp. Mar. Biol. Ecol. 277: 25-41.

Tovar-Hernandez, M.A. \& S.I. Salazar-Vallejo. 2006. Sabellids (Polychaeta: Sabellidae) from the Grand Caribbean. Zool. Stud. 45: 24-66.

Tovar-Hernandez, M.A. \& P. Salazar-Silva. 2008. Catalogue of Sabellidae (Annelida: Polychaeta) from the Grand Caribbean Region. Zootaxa 1894: 1-22.

Turnbull, D. A. 1979. The water quality characteristics and distribution of benthic invertebrates in a polluted harbor, Barbados, West Indies. MSc. Thesis, McGill University, Montreal, Canada.

Uebelacker, J.M. \& P.G. Johnson (eds.). 1984. Taxonomic guide to Polychaetes of the Northern Gulf of Mexico. Barry A. Vittor, Mobile, Alabama, USA. 7 vols.

Wade, B.A. 1976. The pollution ecology of Kingston Harbour, Jamaica. Vol. 3. Pollution abatement and harbor improvement. Research Report 5, Zoology Dept. University of the West Indies, Mona, Jamaica.

Warner, G.F. \& I. Goodbody. 2005. Jamaica, p. 57-70. In Caribbean Marine Biodiversity: The known and the unknown. P. Miloslavich \& E. Klein (eds.). DEStech Publications Inc., Pennsylvania, USA.

Webster, H.E. 1884. Annelida from Bermuda. Bull. U.S. Natl. Mus. 25: 305-327.

Weil, E. 2005. Puerto Rico, p. 85-108. In Caribbean Marine Biodiversity: The known and the unknown. P. Miloslavich \& E. Klein (eds.). DEStech Publications Inc., Pennsylvania, USA. 
